\title{
THE IMPACT OF THE DETERMINANTS OF FOURTH INDUSTRIAL REVOLUTION ON SUSTAINABILITY AND COMPETITIVE ADVANTAGE- A STUDY FOR MALAYSIAN SMES
}

\section{Sreenivasan Jayashree}

Associate Professor, Faculty of Management

Multimedia University, Persiaran Multimedia, 63100 Cyberjaya, Selangor

Malaysia

jayashree@mmu.edu.my

\section{Chinasamy Agamudainambi Malarvizhi}

Senior Lecturer, Faculty of Management

Multimedia University, Persiaran Multimedia, 63100 Cyberjaya, Selangor

Malaysia

malarvizhi@mmu.edu.my

\section{Mohammad Nurul Hassan Reza*}

Research Scholar, Faculty of Management

Multimedia University, Persiaran Multimedia, 63100 Cyberjaya, Selangor

Malaysia

hassanreza7171@gmail.com

*Corrosponding author's Email: hassanreza7171@gmail.com

Peer-review under responsibility of 4th Asia International Multidisciplinary Conference 2020 Scientific Committee http://connectingasia.org/scientific-committee/

(C) 2020 Published by Readers Insight Publisher, Office \# 6, First Floor, A \& K Plaza, Near D Watson, F-10 Markaz, Islamabad. Pakistan, editor@readersinsight.net

This is an open access article under the CC BY-NC-ND license (http://creativecommons.org/licenses/by-nc-nd/4.0/). 


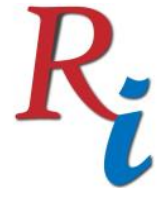

Asia Proceedings of Social Sciences

(APSS)

www.readersinsight.net/APSS

\section{A b s t r a c t}

As one of the leading financial institutions, SMEs involve intense demands from customers and stakeholders. The "Fourth Industrial Revolution" may also be defined as "Industry 4.0" because it has evolved through automation and innovation that can transform products and manufacturing processes by real-time data integration, allowing consumers to be satisfied through customized products. The unique aspect of Industry 4.0 should be investigated and the inherent difficulty in understanding the determinants, as most recent studies address the technological dimension of the concept. This study addresses the effect of the core determinants of Industry 4.0 in achieving sustainability as well as competitive advantage. The findings would provide useful insight into how SMEs should implement the smart technology to accomplish Industry 4.0. This paper presents a conceptual model, including hypotheses, that will be tested further through a quantitative analysis.

\section{Rese a r ch H igh I ight s}

Industry 4.0 involves high productivity, efficiency, and automation (Slusarczyk, 2018; Thames $\&$ Schaefer, 2016). In the manufacturing and service sectors, Industry 4.0 has a transforming and significant role (Imran, 2018; Rüßmann et al., 2015). Industry 4.0 comprises unique characteristics such as internet-based technology and advanced analytics, contributing both to competitive advantage and sustainability (Roblek et al., 2016). The study deals with the determinants of Industry 4.0 that involve a wide range of technological concerns in SMEs and to improve sustainable growth. A conceptual framework is proposed based on three dimensions of sustainability with the integration of the three major determinants of Industry 4.0 and the mediating impact of sustainability between the determinants and competitive advantage.

\section{Research Objectives}

This study involves some particular objective as follows,

- Inspect the effect of the determinants of Industry 4.0 on sustainability.

- Examine the effect of the determinants of Industry 4.0 on competitive advantage.

- $\quad$ Explore the connection between sustainability and competitive advantage.

- Inspect whether sustainability mediates the relationship between the determinants of Industry 4.0 and competitive advantage.

\section{Literature Review}

Industry 4.0 is still ambiguous, although the number of studies has increased steadily in the current years (Muhuri et al., 2019; Brettel et al., 2014). Researchers also claimed that the 


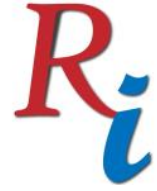

\section{Asia Proceedings of Social Sciences \\ (APSS) \\ www.readersinsight.net/APSS}

determinants of Industry 4.0 must be recognized to assess the aspects of adoption and its successful execution to attain competitive advantage (Sony \& Naik, 2019; de Sousa Jabbour et al., 2018).

Competitive advantage can play a significant role in sustaining a country or an organization's long-lasting stability (Porter, 1990). Therefore, by creating competitive advantage, organizations can always remain ahead of the competition. That explains why competitive advantage has gained tremendous focus from scholars (Arslan \& Tathdil, 2012; Porter, 1990).

Researchers sometimes criticized 'sustainability' as a complex, debatable, and commonly distinctive concept (Lozano et al., 2013); that's why sustainability facets and definitions need to be explored. To attain sustainability and sustainable development, scholars have proposed sustainability from the 'Triple Bottom Line' viewpoint that encompasses profit, planet, and people, including a financial, environmental, and social dimension (Galdeano-Gomez et al., 2013, Choi \& Ng, 2011).

\section{Research Framework}

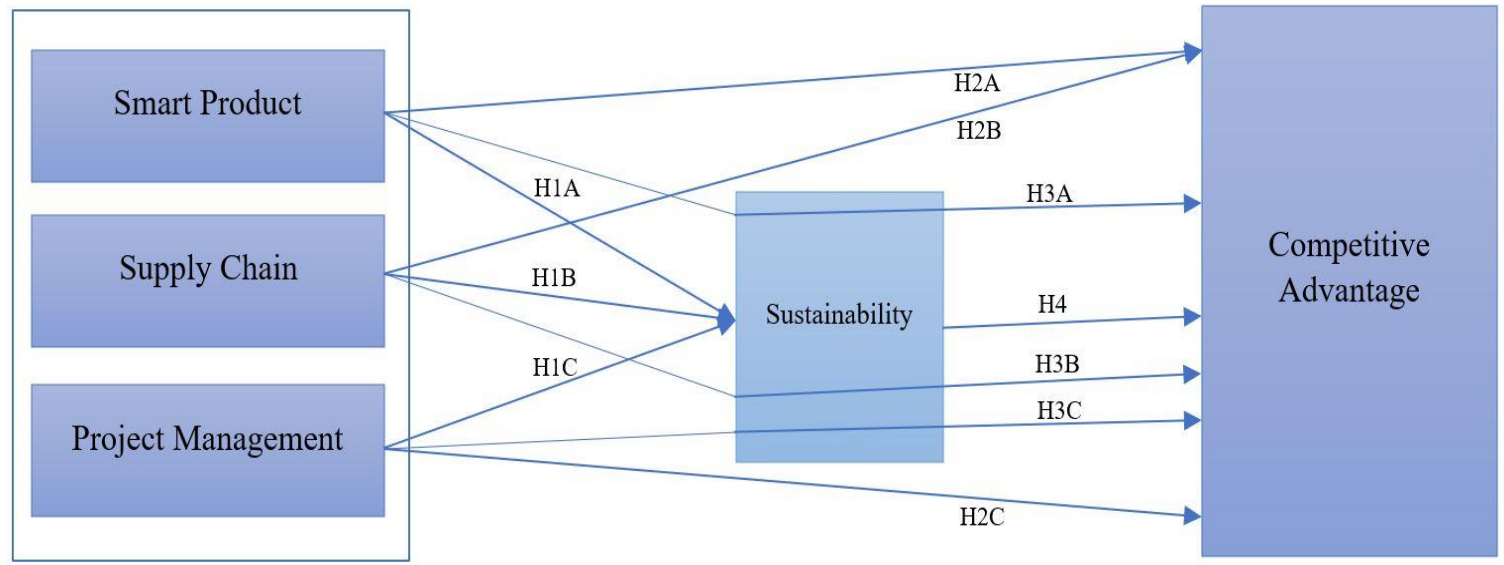

Fig. 1: Research Framework

\section{Smart Product, Sustainability, and Competitive Advantage}

Industry 4.0 involves a range of technological changes, including smart factories and devices, which influence products and procedures to create smart products (Schmidt et al., 2015). Engineering and manufacturing design are combined in a structured system to develop smart products, enabling reduced costs, superiority, and shorter production time (Nafisi et al., 2016), directing organizations to achieve sustainability. Integration of goods, development processes, and the virtual environment would allow the company to self-regulate, track, and manage development. Industry 4.0 enables organizations to self-regulate, track, and maximize productivity by integrating products, manufacturing systems, and cyber-physical systems (Cheng et al., 2016). 


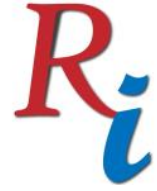

Asia Proceedings of Social Sciences

(APSS)

www.readersinsight.net/APSS

\section{Supply chain, Sustainability, and Competitive Advantage}

The supply chain management approach produces and creates finished goods by and to the company's ultimate buyer (Stadtler, 2008). It enhances confidence and coordination and accelerates inventory development (Jayaram, 2016). An efficient organization requires to link the production and supply chain appropriately. A smart supply chain, including the raw materials at the proper time, proper quantity, and right place, allows organizations to attain competitive advantage in Industry 4.0 (Kovács \& Kot, 2015).

\section{Project Management, Sustainability, and Competitive Advantage}

Various projects will occur in organizations implementing Industry 4.0 than conventional organizations; therefore, effective project management is essential for this concept (Shamim et al., 2016). Project management is a distinct initiative with creativity, invention, and competitive advantage (Davies \& Brady, 2016). DeFillippi \& Arthur (1998) have revealed that project management is a significant factor for an organization to build a competitive advantage.

\section{Methodology}

This study proposes a conceptual framework of Industry 4.0, including the impact of its core determinants on sustainability and competitive advantage. Malaysian SMEs will be subjected to a cross-sectional survey, and samples from SMEs will be chosen. The study will be carried out in different states of Malaysia. The data collection will be carried out using a questionnaire, and the analysis will be done using Structural Equation Modeling (SEM).

\section{Conclusion}

The study aims at evaluating the critical determinants of Industry 4.0 to achieve competitive advantage through sustainability. It will develop knowledge and understanding by creating a successful and efficient model, including the core determinants of Industry 4.0 that can help Malaysian SMEs gain sustainability and competitive advantage in Industry 4.0.

\section{Acknowledgement}

The researchers are grateful to the Ministry of Higher Education, Malaysia, for funding the study under the FRGS grant.

\section{References}

Arslan, N., \& Tathdil, H. (2012). Defining and measuring competitiveness: a comparative analysis of Turkey with 11 potential rivals. International Journal of Basic \& Applied Sciences, 12(2), 31-43. 


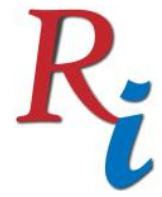

\section{Asia Proceedings of Social Sciences (APSS) \\ www.readersinsight.net/APSS}

Brettel, M., Friederichsen, N., Keller, M., \& Rosenberg, M. (2014). How virtualization, decentralization and network building change the manufacturing landscape: An Industry 4.0 Perspective. International journal of mechanical, industrial science and engineering, 8(1), 37-44.

Cheng, G. J., Liu, L. T., Qiang, X. J., \& Liu, Y. (2016, June). Industry 4.0 development and application of intelligent manufacturing. In 2016 international conference on information system and artificial intelligence (ISAI) (pp. 407-410). IEEE.

Choi, S., \& Ng, A. (2011). Environmental and economic dimensions of sustainability and price effects on consumer responses. Journal of business ethics, 104(2), 269-282.

Davies, A., \& Brady, T. (2016). Explicating the dynamics of project capabilities. International Journal of Project Management, 34(2), 314-327.

de Sousa Jabbour, A. B. L., Jabbour, C. J. C., Foropon, C., \& Godinho Filho, M. (2018). When titans meet-Can industry 4.0 revolutionize the environmentally-sustainable manufacturing wave? The role of critical success factors. Technological Forecasting and Social Change, 132, 18-25.

DeFillippi, R.J. and Arthur, M.B. (1998), Paradox in project-based enterprise: the case of filmmaking. California Management Review, 40, 125-39.

Galdeano-Gómez, E., Aznar-Sánchez, J. A., \& Pérez-Mesa, J. C. (2013). Sustainability dimensions related to agricultural-based development: the experience of 50 years of intensive farming in Almería (Spain). International Journal of Agricultural Sustainability, 11(2), 125-143.

Imran, M. (2018). Influence of industry 4.0 on the production and service sectors in Pakistan: Evidence from textile and logistics industries. Social Sciences, 7(12), 246.

Jayaram, A. (2016, December). Lean six sigma approach for global supply chain management using industry 4.0 and IIoT. In 2016 2nd international conference on contemporary computing and informatics (IC3I) (pp. 89-94). IEEE.

Kovács, G., \& Kot, S. (2016). New logistics and production trends as the effect of global economy changes. Polish Journal of Management Studies, 14.

Lozano, R., Lukman, R., Lozano, F. J., Huisingh, D., \& Lambrechts, W. (2013). Declarations for sustainability in higher education: becoming better leaders, through addressing the university system. Journal of Cleaner Production, 48, 10-19.

Muhuri, P. K., Shukla, A. K., \& Abraham, A. (2019). Industry 4.0: A bibliometric analysis and detailed overview. Engineering applications of artificial intelligence, 78, 218-235. 


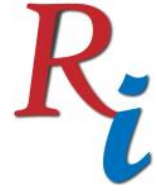

\section{Asia Proceedings of Social Sciences (APSS) \\ www.readersinsight.net/APSS}

Nafisi, M., Wiktorsson, M., \& Rösiö, C. (2016). Manufacturing involvement in new product development: An explorative case study in heavy automotive component assembly. Procedia Cirp, 50, 65-69.

Porter, M. E. (1990). The competitive advantage of nations: with a new introduction. Free Pr.

Roblek, V., Meško, M., \& Krapež, A. (2016). A complex view of industry 4.0. Sage Open, $6(2)$.

Rüßmann, M., Lorenz, M., Gerbert, P., Waldner, M., Justus, J., Engel, P., \& Harnisch, M. (2015). Industry 4.0: The future of productivity and growth in manufacturing industries. Boston Consulting Group, 9(1), 54-89.

Schmidt, R., Möhring, M., Härting, R. C., Reichstein, C., Neumaier, P., \& Jozinović, P. (2015, June). Industry 4.0-potentials for creating smart products: empirical research results. In International Conference on Business Information Systems (pp. 16-27). Springer, Cham.

Shamim, S., Cang, S., Yu, H., \& Li, Y. (2016, July). Management approaches for Industry 4.0: A human resource management perspective. In 2016 IEEE Congress on Evolutionary Computation (CEC) (pp. 5309-5316). IEEE.

Slusarczyk, Beata. (2018). Industry 4.0: Are we ready? Polish Journal of Management Studies, $17,232-48$.

Sony, M., \& Naik, S. (2019). Key ingredients for evaluating Industry 4.0 readiness for organizations: a literature review. Benchmarking: An International Journal.

Stadtler, H. (2008). Supply chain management - an overview. Supply chain management and advanced planning (pp. 9-36). Springer, Berlin, Heidelberg.

Thames, L., \& Schaefer, D. (2016). Software-defined cloud manufacturing for industry 4.0. Procedia cirp, 52, 12-17.

Author's Biography

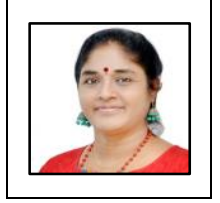

Dr Sreenivasan Jayashree, Associate Professor, Multimedia University, Cyberjaya, Malaysia has widely published in many international journals and has secured many grants. She has supervised many students. Her areas of interest are environmental management, strategic management, Industry 4.0, waste management, consumer studies. 


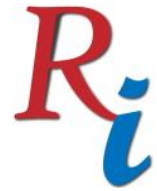

\section{Asia Proceedings of Social Sciences} (APSS)

www.readersinsight.net/APSS

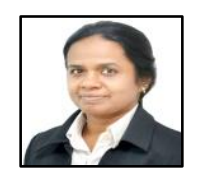

Dr Chinasamy Agamudainambi Malarvizhi, Senior Lecturer, Multimedia University, Cyberjaya, Malaysia has more than 18 years of teaching and research experience in Economics, Environment and Health issues, Knowledge Management and Tourism Development. She regularly publishes in journals and presents at international conferences. She has guided many PhD research scholars, Master students, and undergraduate students.

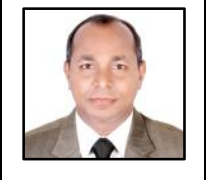

Mohammad Nurul Hassan Reza, Research Scholar, Faculty of Management, Multimedia University, Cyberjaya, Malaysia. Graduate Research Assistant of the project titled 'Testing a Framework for Industry 4.0 Digital Disruption-A Crunch Point for Environmental Sustainability in Malaysian SMEs', Ministry of Higher Education (MOHE), Malaysia. His areas of Interest are Fourth Industrial Revolution, Industrial Management, environmental management. 